\title{
Football Stadiums and the Production of Space in Czech Cities until 1939:
}

Martin Pelc:*:

vol. 9, 2020, 2, pp. 43-59

DOI: https://doi.org/10.33542/CAH2020-2-03

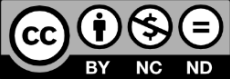

Sport has become a significant part of our lives in the modern era and sporting sites contribute considerably to the image and texture of modern cities. Regarding the popularity of sport, especially football, the stadium has become an important modern space where specific kinds of social interaction take place. Despite the fact modern stadiums had their pre-modern models, they have been transformed substantially, so that we can talk of new urban spaces. This paper shows how football pitches gradually turned into stadiums, using the example of the Czech lands. The choice is by no means autotelic: interwar Czechoslovakia had one of the most successful football teams on the continent.

Keywords: Stadium. Football. Czechoslovakia. Czech Lands.

\section{Introduction}

A "football field" (be it a field for soccer or American football) has become an almost semi-official unit of area over the past century. We use it instead of the official measures when we want to describe how large some place is. According to some tourist guides, the Great Pyramid in Egypt covers an area as large as ten football fields, an antique Roman Circus maximus was as big as five football fields and some mediaeval domes are as big as a football field... The image of a football pitch is so common that we use it almost subconsciously to evoke more abstract terms. It is just one of many examples of how sport has become a significant part of our lives in the modern era.

This paper tracks how sporting sites, especially the aforementioned football fields and stadiums, ${ }^{1}$ were transformed in Czech cities, above all Prague, in the period up until 1939. If we are to analyse the problem theoretically, sport should be handled as a form of physical, competitive play. ${ }^{2}$ Ontologically - according to the phenomenologist Eugen Fink - play takes place in its own inner time (e.g. 90 minutes in the case of association football) and space (the size of the football pitch). Fink also argues that it is not merely the players who may take part in play: a community of play unites those who play and those who watch or otherwise participate. ${ }^{3}$ This can be applied to sporting events, too. In the case of football (prior to the introduction of live broadcasting), the community of play was defined and shaped exclusively by the stadium. Regarding the popularity of sport, especially football, the stadium became an important modern

\footnotetext{
This paper was supported by the Czech Science Foundation under Grant number 19-10401S, "Sport jako podivaná: Zrod sportovního diváctví a fanouškovství v českém prostředí (do roku 1945)" [Sport as spectacle: The birth of sport spectatorship and fan culture in Czech society till 1945].

$*$ Assoc. Prof. Martin Pelc, Ph.D., Historical Institute, Faculty of Philosophy and Science in Opava, Silesian University, Opava, Czech Republic; martin.pelc@fpf.slu.cz

1 Compare for example FLOWER, Sport and Architecture. INGLIS, The Football Grounds of Europe. INGLIS, The Football Grounds of Great Britain. INGLIS, Sigthlines. FISCHER, German Football Stadiums.

2 CAILLOIS, Man, Play and Games, passim

3 FINK, Oasis of Happiness, 23, 25, 27.
} 
space ${ }^{4}$ where specific kinds of social interaction take place. ${ }^{5}$ Despite the fact modern stadiums followed their pre-modern models, they were transformed substantially in the nineteenth and twentieth centuries, such that we can talk of a novelty in the urban space. This paper shows how football pitches were gradually transformed into stadiums, using the example of the Czech lands. The choice is by no means autotelic: inter-war Czechoslovakia was one of the most successful football sides on the continent, alongside Italy, Austria or Hungary. The Czechoslovak national team was the runner-up at the second FIFA World Cup (1934) and its most prominent clubs, SK Slavia Prague and AC Sparta Prague, won the Mitropa Cup, one of the top events of the time, three times within the span of thirteen years $(1927,1935,1938)$.

This study is not intended to give an account of the architectural treatment of the stadium as a form. It rather aims at revealing how the stadium developed as a semipublic zone with its own rules, inner structuring and components that further influenced spectators' perceptions, i.e. how, according to Henri Lefebvre's concept, space "was produced". His concept of the "production of space" is used, encompassing the triad of 1) spatial practices (lived practices in a stadium), 2) the representation of space (abstract or conceptual forms of space, conceptualization of space) and 3) representational space (the experience of space through media). ${ }^{6}$ The study follows the means by which the stadium was singled out from the public space and how players and spectators were progressively divided. I shall also pay attention to the emergence of the first stands, which were perceived as the turning point from a football pitch to a football stadium. Socially, the division of the stands into sectors was of great importance. The sophistication of the spectacle grew and the perception thereof changed as new equipment and devices were installed such as stadium clocks, loudspeakers or floodlights. The establishment of the football stadium as an issue worthy of public discussion was accompanied by a more systematic, expert approach to their (re)building. While the first stadiums developed organically by adding further elements to early football fields, in the interwar period, architects began to approach the stadium as a whole and intended to design it according to the latest expert knowledge from lawn to roof. Simultaneously, provisional wooden constructions started to be replaced by materials for "eternity", such as bricks, stones and, above all concrete, iron and steel.

\section{Football grounds prior to 1914}

Football according to the rules of England's Football Association (soccer) was probably introduced in the Czech or Bohemian lands (Bohemia, Moravia, Austrian Silesia) in the second half of the 1880s. The first permanent clubs played the game from the first half of the 1890s. The foremost centre of the game was Prague, which could even compete with the Empire's capitals, Vienna and Budapest. Early football in Central Europe used non-sport areas at first. There were only a few large, undeveloped plots within the city limits and almost no agriculturally unused land in the surrounds. In many cities, only army exercise areas could afford an area of flat ground large enough to serve as a football pitch. Such was the case of the Tempelhofer Feld in Berlin and

\footnotetext{
4 LEO, Das Stadion. RANDL, Das Fußballstadion.

5 BALE, Sport, Space, and the City. BALE, Landscapes of Modern sport. BALE - MOEN, The Stadium and the City. TERRET - HECK, Sport and Urban Space in Europe. FRANK - STEETS, Stadium Worlds. RIESS, City Games. HOLZMEISTER, A brief history of soccer stadiums in Brazil.
}

6 LEFEBVRE, Production of Space, passim. See also FLOWERS, Stadiums. 
of grounds in many other capital and provincial cities. In Prague, Letná (in German, Belvedere) - which sometimes had been used as an exercise or parade area in the past, too - became the home of the three foremost clubs: Deutscher Fußballclub Prague (DFC), SK Slavia Prague and AC Sparta Prague. Until the 1940s, it probably represented a globally unique vicinity of football rivals and, retrospectively, perfect comparative material for urban historians. In the 1890 s, football had also been played on the Kaiserwiese (Císařská louka) - a large meadow on the Moldau (Vltava) - and in the Hôtel des Invalides' (Invalidovna) park. ${ }^{7}$

Since the football grounds had not been surrounded by any barrier yet, they were initially part of the urban public space. They were even moved from one match to another: the press informed for instance that the football pitch would find itself "10-15 minutes further up the river, between the 'Red Garden' and the distillery, this time" before the match between Prague's (Eisclub) Regatta ${ }^{8}$ and Germania Berlin in March $1894 .{ }^{9}$ They were turned into a semi-public zone to which entrance tickets were demanded for admission as soon as they began to be enclosed. ${ }^{10}$ The first club to do so was the above mentioned leading side of early football in Prague, Regatta. The motivation was not economic, contrary to what one might expect. Regatta was a high-class club supported by well-to-do Prague Germans, often Jewish. The collecting of entrance fees was seen by them as a form of social exclusion and regulation. The construction of a wooden fence around Regatta's Kaiserwiese pitch in the autumn of 1896 was thus interpreted from a moral point of view: "to strip the dear mob (süßen Mob) of the opportunity to disturb the play". ${ }^{11}$ The same applies to the enclosure of the new DFC Letná football ground that the club had acquired 1897, having previously played at Císařská louka, too. The press argued that "as soon as the D. F. C. sporting ground is completed [i.e. including the wooden fence], the criminal acts of the not very kind mob are going to come to a halt". ${ }^{12} \mathrm{~A}$ year later, the socially exclusive DFC increased the height of the fence in order to prevent the lower strata spectators from shouting "obnoxious cries" while watching the game from upon various objects they had brought with them. ${ }^{13}$ When Slavia, a Czech but also socially exclusive football club, opened its new football ground on Letná Plain in 1901, it lacked the wooden enclosure used by Regatta or DFC. Unlike its German neighbour, Slavia had only a wire mesh fence built, so large canvases bearing advertisements had to be put on it before each match. When the wind was too strong, this was not possible and most spectators would then watch the game from behind the fence. ${ }^{14}$ The trend to surround football grounds with a wooden barrier, however, soon became universal, marking the end of the osmotic spectatorship of the early years.

7 On the early history of football in Prague, see for example ZWICKER, Allerlei Pioniere. KUŽEL, Společenskoekonomické proměny.

8 Vereinigter Eis- und Ruderclub Regatta, since July 1896 Vereinigter Ruderclub und Fussballclub Regatta. Archiv hlavního města Prahy, Magistrát hlavního města Prahy II., Spolkový katastr, k. 584.

9 Dr. R. [ROSENBAUM], Fußballwettspiele, 4.

10 See for example BALE, Stadien.

11 Prager Tagblatt, 24. 10. 1896, no. 293, 6.

12 Fußballwettspiele, Prager Tagblatt, 26. 3. 1897, no. 85, 4.

13 Deutscher Fußballclub gegen Akademischen Sportclub 6:2, Prager Tagblatt, 25. 4. 1898, no. 114, 3.

14 OLSEN [pseud.], Nové hřiště Slavie, column 352. R-r [REISNER], Sportovním týdnem, column 75. 
The first ever football match of an Austro-Hungarian team against a British side was played by SK Slavia Prague and Oxford University AFC on 28 March 1899. From then on, matches against British teams became fixed events in the calendar and the financial demands on clubs grew. New facilities had to be built too, in order to meet the requirements of the guests. As a result, even exclusive clubs could not cope without drawing entrance fees from lower strata spectators. Still, the "audience" of Slavia matches around 1900 was described as "Prague's best families". To keep the upper and lower classes apart, divided sectors had been introduced. The new Slavia playing field had two entrances, the first one to the more expensive, the second one to the cheaper stands. Social exclusion was replaced by social segregation.

Slavia also built its first proper clubhouse in 1901. Apart from the facilities for the players and a club room, the timbered pavilion offered eleven boxes on the first floor. Almost simultaneously, a half-timbered clubhouse was built on the adjacent DFC football ground. These buildings gave the well-to-do spectators the first opportunity to watch the game "from above", foreshadowing the modern terraced stands that appeared in Prague after World War I. The press announced that: "To see a match from there is going to be breath-taking". ${ }^{15}$ Most spectators had to settle for stands of heaped soil that granted the rear rows a sufficient view. In the imperial capital Vienna for instance, the stadium Hohe Warte used the hillside as natural stands. The relatively flat grounds of Letná Plain did not enable this though. The stands had to be heaped artificially. In front of them, there was usually a number of chairs for women and club members. Other spectators had to stand behind a simple wooden handrail, a "barrier", that became a synecdochic term for spectators. "To play for the barriers" meant "to play showily but ineffectively" in Czech.

Until 1918, there were no real football stadiums in the Czech lands. Even the term "stadium" was reserved almost exclusively for Olympic sporting sites. Most of the sports architecture in Bohemia used the so-called Swiss style prior to 1918, i.e. wooden constructions with carved decorations. Some $\mathrm{Czech}$ architects were inspired by the Olympic stadiums in London (1908) and Stockholm (1912) though and planned the first "stone stadium" in Prague. Even before the Olympic Games in London, Czech NeoRenaissance architect Jan Koula drafted a solid multi-purpose stadium on Prague's Letná (1907) but there was not enough financial support for his idea. ${ }^{16}$

The existing football grounds afforded a sufficient capacity for the stagnating attendance figures of the first decade of the twentieth century: between 1901 and 1910, the popularity of football grew but the most attractive matches against British teams were too repetitive and lacked the competitive rivalry to draw larger masses. The London side Corinthian FC, that promoted association football around the world, set a new spectator record against Slavia with approximately 6,000 persons in $1904 .{ }^{17}$ When English league winners Manchester United played against Slavia on 10 May $1908,5,800$ spectators came..$^{18}$ Another new record was set on 14 May 1911 at a match between Slavia and Aberdeen FC when 6,500-7,000 people watched. ${ }^{19}$ The situation changed dramatically between 1912 and 1914 when spectator numbers doubled.

OLSEN [pseud.], Nové hřiště Slavie, column 368.

ŠVÁCHA, Demokratizace sportu, 54, 58.

Národní listy, 10. 4. 1904, no. 100, 13.

Národní listy, 12. 5. 1908, no. 131, [5].

Aberdeen F. C., Národní listy, 16. 5. 1911, no. 134, 5. 
Sparta were able to upset the previously unquestionable hegemony of Slavia by then, making their derby matches more attractive. On 2 June 1912, their encounter was attended by an unprecedented crowd of $10-12,000$ people. ${ }^{20}$ Their last match before the outbreak of World War I drew even more spectators $-14,000$, with thousands more prevented from entering the stands by the police. The capacity of the football grounds had reached their limits by that time. Shortly afterwards, Sparta announced their intention to build a stadium for $20-30,000$ spectators. ${ }^{21} \mathrm{~A}$ new football ground with an increased capacity was opened in 1917.

\section{From football ground to stadium}

Though some architects, as shown above, had dealt with the idea of stadium construction before 1914, the topic was accepted by the experts as a legitimate problem to be solved systematically in Czechoslovakia after World War I. A signal of a new approach to sporting sites was given by the Czech architect Karel Polívka who published a paper entitled "Stadiums" in the Czechoslovak Architects' Journal (Časopis československých architektů) in 1924. He not only introduced the topic to the professional community but also anticipated "stadiums for eternity", built of solid materials instead of wood. Among the examples to be followed, he mentioned the Olympic stadiums in Stockholm and Anvers, but also a number of American stadiums (Yankee Stadium in New York City and Franklin Field in Philadelphia). ${ }^{22}$ Jaromír Krejcar was inspired by the Pittsburgh stadium when drafting a stadium for Letná Plain in Prague. ${ }^{23}$ Olympic stadiums continued to influence the architects in the 1930 s (with the Olympiastadion in Berlin to the fore).

Indeed, there was a stadium built of concrete and iron in Prague in 1922. The large multi-purpose stadium - generally called Trotting Stadium - existed for only eight years before it was torn down as oversized, uneconomical and unnecessary in 1930. The Women's World Games in 1930 turned out to be its swan song. It found itself between the Sparta and Slavia grounds on Letná Plain. Its proportions, however, made it utterly unsuitable for the most popular sport - football. ${ }^{24}$ For this reason even international matches were mostly played in the Sparta stadium, which then offered the greatest capacity. Another giant stadium, even larger than Trotting Stadium, was built for the mass gymnastic "feasts" (slety) on Strahov Hill. With massive financial support from the state and the city council, Sokol (Falcon) and other gymnastic organizations were given one of the largest stadiums of the world. Its construction of concrete and iron was not completed until World War II broke out. The megalomaniac project triggered a new period of specific Czechoslovak rivalry between sporting organizations and the Sokol movement. The Czechoslovak Sports Community, an umbrella organization of most of the sporting fields, claimed the state should also build a multi-purpose sports site to outweigh the support of the mass gymnastic feasts. There was even a largescale demonstration in which various sports associations marched through Prague on 18 September 1927 demanding a "national stadium" be built. Long discussion was

20 Slavný den české kopané, Národní listy, 3. 6. 1912, no. 151, 3. Zápas Sparta - Slavia, Sport a hry, 5. 6. 1912, no. 24 (541), 276.

21 Sport 2, 15. 4. 1914, no. 8, 2, 13.

22 POLÍVKA, Stadiony.

23 KREJCAR, Zachraňte Letnou pro sport.

24 ŽENATÝ, Všesportovní stadion v Praze, Stavitel 4, 1922-1923, Technická a konstruktivistická hlídka, 5-6. 
triggered as to whether such projects should be realized by the state. Some called it the Olympic complex while Czechoslovakia planned to apply to be the host of the Olympic Games of 1932. A compromise was eventually found. The state promised to build a multi-purpose stadium (suitable for football) near the Strahov Sletový stadion. It was eventually opened in 1935 and will be mentioned below. ${ }^{25}$ A number of experts, among them many architects, joined the lengthy discussions provoked by this manifestation.

Since the mass gymnastic movement looked back at a longer tradition and could be utilized by state propaganda more effectively than competitive and commercialized sports such as football (in 1925, professionalism was introduced in Czechoslovak football), the clubs had to rely on themselves for most of the period. There was one more obstacle for all three of the most important clubs in Prague: Letná Plain, where their football grounds found themselves, was a municipal or later state property. The clubs owned their "stadiums" but not the plots underneath them. Thus they were reluctant to invest any larger amounts of money. As the press put it in 1930: "The city council would not allow it anyway." 26 So the stadiums grew organically, various components being added in different styles over the years, resulting in an aesthetically not very pleasant whole. The above-mentioned architect Karel Polívka expressed himself openly regarding the most modern (!) football stadium in Prague - the Sparta stadium - in 1937: "as a whole, it is a deterrent example of an unsystematic adaptation in regulatory, infrastructural, operational and aesthetic sense". ${ }^{27}$ The site was nicknamed, somewhat sarcastically, the Stonehenge of Letná due to the similarity of its entrance pylons to the famous prehistoric monument.

During the interwar period, the Czechoslovak state planned to build an ensemble of representative buildings housing various ministries and the republic's parliament on Letná Plain. They were intended to represent the new Czechoslovak republic as a democratic, modern, economically potent and ambitious state. The plan was, however, overblown and only a fragment of it was realized. Nevertheless, the Sword of Damocles was hanging, over the Slavia and DFC grounds especially, over the two decades of the first Czechoslovak Republic. ${ }^{28}$ Meanwhile, minor or provincial clubs acquired modern, medium-scale stadiums that were drafted and functioned as a whole. Pardubice in particular, a host city of the first great State Exhibition of Physical Culture and Sport in 1931, ${ }^{29}$ boasted a modern multi-purpose stadium in the up-to-date "white functionalistic" style (designed by Karel Řepa). AFK Vršovice (i.e. Bohemians, Alois Vejvoda) got a new stadium in $1932,{ }^{30}$ and various other clubs followed in $1938-1940 .{ }^{31}$

The stands: towards a "perfect view"

Until 1918, football grounds in Bohemia lacked the terraced stands that are perceived generally as a signature feature of a football stadium. The boom of football

25 PELC, Národní stadion; See the chapter "Stadion jako téma a problem" in PELC, Sport a česká společnost, 79-92.

26 Opojným triumfem nad mistry Italie získala A. C. Sparta nejen postup do Středoevropského poháru, Pondělní list, 13. 10. 1930, no. 285, 6.

27 ŠVÁCHA, Sport v Československé republice, 118.

28 See for instance KREJCAR, Zachran̆te Letnou pro sport.

29 Oficielní katalog.

30 Pestrý týden, 7, 9. 4. 1932, no. 15, 17.

31 For an interesting comparation see MÜLLNER, Wiener Stadion. 
spectatorship shortly before 1914 showed they were no longer dispensable if all visitors were to enjoy a satisfactory view of the pitch. After 1918, sport became not only popular, but was hailed as an epitome of the new "free and democratic" order of the post-war world. After four years of suffering and misery, the demand for entertainment grew. On 7 November 1920, the match between Sparta and DFC was watched by a recordbreaking crowd of 20,000 visitors, and a year later, on 18 September 1921, the match between Sparta and the Austrian championship winners Rapid Vienna drew an even greater $25-28,000$ spectators. The press reported that a stadium for 50,000 spectators would soon be needed. ${ }^{32}$ In 1930, the maximum attendance exceeded 30,000 spectators (AC Sparta Prague vs AS Ambrosiana, i.e. Inter Milan). ${ }^{33}$

To comply with this growing demand for football, the first wooden terraced stands were built just after 1918. The short time needed to complete them shows just how simple some of these constructions were. Some of them were put together in a hurry before an upcoming important match, such as the new stands of the Slavia stadium (before the derby match against Sparta) which took only a week to build in March 1919. ${ }^{34}$ But it was Sparta that opened the first real terraced stands meeting up-to-date standards in 1921. They were mostly referred to as "giant" or "overwhelming" stands by the time of their completion. ${ }^{35}$ They were covered by a roof, granting a hitherto unexperienced comfort to Prague football visitors. Their city rivals Slavia also built new wooden stands in $1921 .{ }^{36}$ Apart from "stands" or "terraces", the word (kryté) plaky, i.e. terraces covered by a lower shelter roof, was also used in Czech. The golden age of wooden stands in Czechoslovakia lasted until the mid-1930s when further modernization turned out to be inevitable.

The days of the wooden stands seemed to be numbered in 1934 when a series of incidents occurred. First, the main stands at Sparta Stadium burnt down completely on 10 April 1934 wreaking not only material but also symbolic damage, the club's archive also having been destroyed in the conflagration. ${ }^{37}$ On 2 December 1934, part of the wooden stands at Slavia Stadium collapsed under the stamping feet of the spectators before the autumn season's climactic match between Slavia and Brno's SK Židenice, causing over a hundred injuries and the death of one football fan. ${ }^{38}$ An inspection at the neighbouring DFC stadium subsequently resulted in the closing of its stands. ${ }^{39}$ Spectator sport in Prague was struck badly and both Sparta and Slavia had to consider either a thorough reconstruction of their "stadiums" or the construction of new ones. While Sparta decided to build new main stands in 1934, Slavia, who were still striving for a long-lasting lease of the plots underneath their football ground from the state, organized an architectural tender for a new stadium for at least 50,000 spectators

32 Sparta poráží Rapid 4-1, Sportsman, 21. 9. 1921, no. 135, 1. AC. Sparta vítězí nad DFC. 4-1 (2-0), Sportsman, 11. 11. 1920 , no. $86,1$.

33 Opojným triumfem nad mistry Italie získala A. C. Sparta nejen postup do Středoevropského poháru, Pondělní list, 13. 10. 1930, no. 285, 6.

34 Slavia - Sparta 3-2 (0-1), Sportsman, 2. 4. 1919, no. 2, 1.

35 Dánové v Praze, Čas, 29. 3. 1921, no. 70, 2. Boj o mistrovství republiky, Večer, 18. 6. 1921, no. 136, 4.

36 S. K. Slavia v r. 1921, Národní listy, 19. 2. 1922, no. 50, 10.

37 See for example the retrospective Tribuna AC Sparta symbolem živelné síly a rozmachu sportu, Polední list, 10. 12. 1936, no. 344,8 .

38 See for example Der Tod eines Fußballfanatikers, Prager Tagblatt, 4. 12. 1934, no. $284,4$.

39 Důsledky neštěstí na Slavii, Polední list, 14. 12. 1934, no. 346, 8. 
in 1935 . Some sources claimed that the new stadium was going to be designed for 70,000 spectators. 40

Unlike the simple wooden constructions of the early 1920s, the new solid terraced stands at Sparta Stadium took two years to complete (1935-1936, designed by the trio Nedvěd, Bauer and Hudec) and swallowed over 2 million crowns (the estimated cost of the entire Slavia Stadium was Kč 6.5 million in 1936). ${ }^{41}$ Interestingly, the main stand at Sparta serves as the VIP-sector to this day, showing that the long-term plans of stadium construction in the second half of the 1930 s were by no means mere daydreams. In Czechoslovakia, the new Sparta stand was unprecedented in both size and technical complexity. First of all, it offered 25 rows of seats plus 28 numbered boxes at the front. Wooden benches were replaced by individual seats. Football spectatorship was becoming an activity enjoyed while sitting instead of standing, lending it a more theatrical, civilized flavour.

The relatively steep stands and, above all, the 1:2 ratio between the terraces' height and depth (i.e. $40 \times 80 \mathrm{~cm}$ ) ensured a satisfactory view for all spectators. The upper rows found themselves at a height equivalent to a four-floor building, granting a brand-new form of experience for many, as the press revealed. The whole was covered by a somewhat overlapping corrugated iron roof, providing welcome shelter from the rain. Simultaneously, this did not hinder the view of the any of the pitch, since only four subtle riveted pillars supported it, as opposed to ten in the case of the old wooden stands. If the old wooden stands worked as a frame for a landscape scene, the view from the new stand resembled rather a panoramic painting, an all-encompassing view with seemingly no boundaries. It also offered a higher level of services: the interior was divided into a restaurant and club section. Nevertheless, most of the spectators had to stand on the old terraces. Sometimes they sat at a reasonable height on the edges of the wooden terraces to be able to see the game.

At the end of the period, between 1938 and 1940, two company sports clubs had modern functionalistic stands built in the province that could compete with the one at Sparta stadium: the first one being the ASO Olomouc stadium (designed by Bohumír Čermák), the second - a multi-purpose venue - the stadium of the Vítkovice Ironworks (designed by Jaroslav Kincl, Lev Krča and Stanislav Tobek), both in Central or North Moravia. ${ }^{42}$ In 1935, the Masaryk stadium on Strahov Hill, the national sports stadium, was finished after long years of discussions and plans, near the giant Sletový Stadion. ${ }^{43}$ It was not only an answer to the above-mentioned debates but also a means of state representation, hence the naming of the whole Strahov complex after President Tomás Garrigue Masaryk. It was due to be opened with a reprise of the previous year's World Cup final matchup of Czechoslovakia vs Italy on 27 October 1935 (a day before the anniversary of the (zechoslovak state) to emphasize the role the state played in the support of sports. The plans were changed after Sparta reached the Mitropa Cup finals somewhat unexpectedly, having relegated Juventus Turin in the semi-finals in an additional third play-off match on neutral ground. The final return match against Ferencvárosi TC thus became the first to be played at the new, not quite finished

40 Sty-, Slavia obohatí náš sport velkolepým stadionem! Nedělní list, 14. 11. 1937, no. 316, 14.

41 Tribuna AC Sparta symbolem živelné síly a rozmachu sportu, Polední list, 10. 12. 1936, no. 344, 8. Nedělní list 14. 11. 1937, no. 316, 14.

42 ŠVÁCHA, Demokratizace sportu, 118.

43 BALCÁREK - KOPP, Masarykův státní stadion na Strahově, 109-121. 
stadium on 15 September 1935.44 It immediately broke the attendance record, the stadium boasting a capacity of 45,000 people. The final was watched, however, by an estimated crowd of 55-62,000 spectators.

The press blamed the state for the stadium being too small for the fans' demands upon its completion. ${ }^{45}$ The architects, young functionalists Ferdinad Balcárek and Karel Kopp who had taken over the Strahov Stadiums' construction after Alois Dryák's death in 1932, experimented with a roof construction without any supporting columns. They strengthened the roof's ribbing and the consoles so that nothing hindered the spectators' view. ${ }^{46}$ This was, however, not technically possible on a greater scale, so only a minor part of the stands was roofed (13\%, i.e. 5,954 plus the "VIP" boxes). This - alongside other problems (visibility, the exposed and windy location of the stadium, poor administration of the stadium allowing the capacity to be surpassed during important matches) - led to a paradoxical situation: although Czechoslovakia finally had a national stadium, some international matches were still played at the somewhat smaller but better suited and located Sparta Stadium.

The media often compared the new national stadium in Prague to the Praterstadion in Vienna built between $1928 / 9$ and 1931, with a few exceptions in favour of the Austrian arena. ${ }^{47}$ The comparison to Vienna is quite significant and should be commented on more precisely. If we are to refer to the specific development and particularities of football stadiums in Prague, Vienna serves as the perfect measure. Vienna was not only geographically close to Prague. It also looked back at a long period of common history of football prior to 1918 and shared numerous personal, economic, cultural and competitive interconnections from 1918 to 1938. Only Hungary (Budapest) could boast nearly such intensive football relations to Czechoslovakia. Austria and Hungary were, for instance, the most frequent opponents of the Czechoslovak football national team - both playing 17 international matches against Czechoslovakia between 1925 and 1938, in contrast with a mere three matches against neighbours Germany and Poland, and two against Romania. ${ }^{48}$ There was also a high number of player transfers between these countries, the trio accepting professionalism in football at almost the same time in the mid-1920s. The relations between Prague and Vienna were even tighter in popular culture. This was partly due to the hundreds of thousands of Czechs living in Vienna (Czechoslovak internationals Josef Bican and Rudolf Vytlačil were born in Vienna or Schwechat), the common Cisleithanian tradition and German language usage in both cities (in Prague as the second language after (zech).

There were, however, significant differences, too. Why, for instance, was it that the rather fledgling economy of post-World War I Austria was able to finance the construction of the giant Praterstadion (today's Ernst-Happel-Stadion) between 1928/9 and 1931, whereas the relatively stable and prosperous Czechoslovakia came up with its national stadium as late as 1935 ? The leftist municipal administration of Vienna of

44 Středoevropský pohár, Sparta a Praha zajímají celý svět, Polední list, 13. 9. 1935, no. 254, 8.

45 PELC, Národní stadion, 84.

46 Another example of this technical solution was Václav Slavík's competition winning draft for the Slavia stadium in 1937. Stavba 13, 1936-1937, 101. See also ŠVÁCHA, Demokratizace sportu, 116.

47 PELC, Národní stadion, 84. MÜLLNER, Wiener Stadion.

48 This context was presented by the author at the international symposium Demokratická monarchie, nedemokratická republika? Kontinuity a zlomy mezi monarchí a republikou ve střední Evropě organized in Olomouc on 12 April 2018 by the Permanent conference of Czech and Austrian historians on common cultural heritage. The presentation should appear in the conference proceedings under the title PELC, Fotbal jako faktor. 
1918 till 1934 was the key to that discrepancy. The so-called Red Vienna social project encompassed not only public housing but also social and health services, including sports. ${ }^{49}$ The rather centrist (partly right-wing) municipal council of Prague was not able to realize its support of sport effectively and of ten handed the initiative over to the clubs or the state. The Strahov national stadium was built by the state, partly to balance out the financial backing of the Sokol gymnastic movement. This double-track national stadium construction in Czechoslovakia - split between the Sokol gymnastics and the broader sports movement - did not work effectively enough. The outcome was not satisfactory: the overall design and the shallowly raked stands of the Masaryk sports stadium could not match the compactness and steep terraces of the Praterstadion, which granted a better view of the pitch.

If we compare the stadiums of the football clubs in Vienna and Prague, the main difference is not to be seen in their architecture: rather utilitarian solutions were still used in both capitals, wood prevailed as the building material, parts of the stands took advantage of the natural terrain's relief (such as at the Hohe Warte) or just used heaped soil. Major differences resulted though from the relative sizes of the two cities and the locations of their most popular sporting sites. The urbanistic problems of a stadium, for instance transport connections with the rest of the city, were dealt with differently. Vienna had ca 1.9 million inhabitants in the 1930s, Prague ca 900,000. While the Letná plain stadiums of Sparta, Slavia and DFC could be seen as a part of the wider city centre, not further than $1.5 \mathrm{~km}$ from the Old Town Square, the Praterstadion, the Hohe Warte or even the Rapid Vienna stadium were situated 4, 5 or $10 \mathrm{~km}$ respectively from the Stephansplatz.

The fans both in Prague and Vienna preferred to travel to games by tram. ${ }^{50}$ Some sources suggest that Viennese spectators used bicycles more frequently, ${ }^{51}$ perhaps thanks to the longer distance to the stadium and the rather flat terrain of Vienna. Prague's Letná plain was strategically better located - moreover, the most popular clubs, Sparta and Slavia, plus the city's best German team DFC Prag, had their stadium there. This enabled the visiting of three top matches in one day. Urbanists were, however, worried by a considerable problem for decades: the precipitous slope of the Letná hill represented an intricate obstacle for modern traffic to and from the historic city centre. That is why there was a funicular in operation between 1891 and 1922, which was substituted by an escalator between 1926 and 1935. Regular traffic thereof was started significantly on the occasion of the derby match between Sparta and Slavia on Sunday 21 March 1926. Masses of fans used it frequently, as is shown in the - perhaps very first on the continent - feature film about football fans, Muži v offsidu (1931) based on the eponymous novel by Karel Poláček published in the same year. ${ }^{52}$ This ground-breaking literary work containing some brilliant observations on the inter-war fan culture is still sadly ignored by most Anglophone authors. ${ }^{53}$

49 WEIHSMANN, Das Rote Wien, 194. MARSCHIK, Bewegte Körper, passim.

50 See for instance HORAK - MADERTHANER, Mehr als ein Spiel, passim.

51 There has not been any photographic evidence found of massive bicycle usage by football fans as it is documented for Vienna. See for instance the photograph of parked bicycles on 6 May 1936 during the match Austria - England. Fotobanka ČTK, ID no. F202006091649201.

52 POLÁČEK, Muži v offsidu. The film Muži v offsidu was directed by Svatopluk Innemann.

53 Most recently, see McGOWAN, Football in Fiction. 
The immense growth of spectator numbers brought about not only the need for larger stands but also for a rational "logistics of the masses" 54 and a comprehensive system of orientation therein. The main goals were the fluent arrival and departure of the crowds, their overview of the whole field and easy orientation in the stands. Traditionally, the various locations on the stadiums were referred to as: II. place for standing (the cheapest); I. place for standing, seated places, boxes and seats along the sideline (most expensive). At some matches, the seats along the sideline (in front of the wire netting fence) had to be removed due to complaints from the rivals: this was for instance demanded by Juventus Turin for the second round match of the Mitropa Cup against SK Kladno, a minor club in Central Bohemia in $1938 . .^{55}$ In contrast to that, 2,000 extra seats along the sideline were allowed for the final match between Slavia and Ferencvárosi TC that year. ${ }^{56}$ Children, however, were mostly allowed to sit right behind the sidelines at most of the matches.

The rows of the terraces could be numbered long before but no exact place could be reserved individually until seated stands were introduced. Around 1935, as the stands grew bigger, old forms of orientation were not sufficient any more. For the Mitropa Cup final between Slavia and Ferencvárosi TC in 1938, Masaryk National Stadium was also divided into sectors of different colours that corresponded with the colours of the entrance tickets. This method was also used at least by some of the drafts for the new Slavia stadium 1936. ${ }^{57}$ More "intuitive" means of orientation were used for the seated stands, too. The new terraces with 3,000 seats at Sparta stadium were divided by the aisles into three sectors, each of which bore one of the club's colours (blue, red, yellow). Apart from this, each seat could, of course, be defined precisely now as a coordinate combining the numbers of the horizontal and vertical rows. ${ }^{58}$

\section{The barriers: safety first}

After football attendances gained mass dimensions in the interwar period, more sophisticated barriers between the players and the spectators had to be invented to prevent the spectators from walking onto the pitch. The play community became progressively divided, though "friendly invasions" of spectators onto the field after the match were tolerated. The fans used to carry the winning team on their shoulders after important wins. The traditional wooden banisters were gradually replaced by plank fences with the upper part made of wire mesh, sometimes with barbed wire on top. In the 1930s, the structures dividing the space inside the stadiums became even more complex. In front of some wooden stands, such as the provisional terraces at Sparta Stadium, there was a double fence in front with a space for the organizers, the police and the services.

From the mid-1930s, concrete barriers came into use. A low concrete wall with wire fencing enclosed the new Masaryk National Stadium in 1935. During the Mitropa Cup final on 13 September 1936 between AC Sparta Prague and FK Austria Vienna, the organizers once again allowed the stadium's capacity to be exceeded by 15,000

\footnotetext{
54 BECKER, Logistik der Massen.

55 Chybná taktika Kladna příčinou porážky v Turíně, Polední list, 11. 7. 1938, no. 190, 8.

562000 nových sedadel na Slavia - Ferencváros! Polední list, 31. 8. 1938, no. 241, 6.

57 O. F., Referát Slavia - Ferencváros upřímně od plic, Moravská orlice, 6. 9. 1938, no. 206, 6; SK. Slavia si postaví na Letné nové hřiště, STAR 10, 1936, no. 13 (523), 9.

58 Spartanská tribuna pod střechou, Expres, 15. 1. 1936, no. 1, 6.
} 
spectators. The stands were literally bursting at the seams and part of the wall collapsed, one year after its completion. The architects argued concrete should wear better than wood but the barrier proved too thin for the unexpected crowds. The mistrust in the new stadium led the Czechoslovak Football Association to transfer the upcoming international match against Germany from Strahov to Sparta Stadium. To divide the large stands, thus disabling dangerous movements of the standing crowds within the stands, wooden "breakwater" barriers were designed after the incident. ${ }^{59}$

In front of the new stands at Sparta Stadium, a fence of thin iron bars that did not affect visibility from the terraces was built. In the late 1930 s, new forms of separation of the stands were employed. Deep concrete ditches, 1-1.5 meters lower than the football field, surrounded the pitch. They were primarily intended as drainage, but secondarily they separated the spectators from the players. This function was emphasized by a fence that was an integral part of the ditch, firstly to prevent accidental falls and secondly to put another obstacle in the way to the pitch. This solution was used by Jaroslav Kincl, Lev Krča and Stanislav Tobek at Vítkovice Ironworks Stadium ${ }^{60}$ and by Jaroslav Hlaváč and Daniel Knotek in their draft of the municipal stadium in Náchod (1941).61

\section{Stadium clocks, loudspeakers, floodlights: a complex experience}

The spectators' perception of a football match was becoming more and more complex and faceted during the interwar period. Some stadiums were equipped with loudspeakers that announced important information on the match as well as organizational matters, adding to the "soundscape" of the stadium. Efficient sound systems appeared in Czech stadiums around 1930. They were also used for the official greetings before the matches, and before the international match between Czechoslovakia and Yugoslavia of September 1934 their national anthems were played over the loudspeakers of the Slavia stadium instead of using the usual live brass band. During the half-time of some important matches, commercials were played as well. ${ }^{62}$ When there was another simultaneous sporting event, they were also used to inform the spectators of the other score or outcome. During the motorcycle speedway Grand Prix at Strahov Stadium in Prague, for instance, "the giant loudspeakers" were said to announce the score of the parallel Mitropa Cup final of Ferencvárosi TC vs Sparta being played in Budapest. ${ }^{63}$ As Barbara Keys put it, sport spectatorship was not only "oculocentric": it encompassed other senses too, with hearing playing a very important role in the emotional experience of the fans. ${ }^{64}$

Large clocks were placed at Czechoslovak stadiums in order to enhance the spectators' orientation in time in the 1920s. Sporting events (as a form of play) take place not only in the concentrated space that is the actual topic of this paper but also in a concentrated time. A specific production of time should therefore be mentioned in

59 Správní sbor Masarykova stadionu přislíbil úpravu hlediště, Polední list, 16. 9. 1936, no. 259, 8.

60 KINCL - KRČA - TOBEK, Sportovní stadion Vítkovických železáren v Moravské Ostravě-Vítkovicích, 84. ŠVÁCHA, Demokratizace sportu, 118.

61 HLAVÁČ - KNOTEK, Soutěžný návrh stadionu pro město Náchod, 203.

62 Zdařilá odveta za Zagreb, Pondělní list, 3. 9. 1934, no. 245, 6. Postup Sparty do finále ohrožen, Polední list, 18. 9. 1931, no. 260, 6.

63 Pražští footballisté v neděli na IV. velkou plochou dráhu, Polední list, 7. 9. 1935, no. 248, 8.

64 KEYS, Senses and Emotions in the History of Sport, 21-38. See also GAFFNEY - BALE, Sensing the Stadium. 
short, too. If we look at the triad of football fields at Letná Plain (Sparta, Slavia, DFC), they could use the nearby water tower's clock as the reference point when necessary until house construction in the late 1930 s overshadowed it. This was, however, a rather coincidental and provisional means of time control. Moreover, it did not provide for orientation within the span of the 45-minute football half.

Time was becoming a public commodity in Czechoslovak football stadiums around 1925. Slavia installed a "giant Omega clock" in its stadium before the start of the spring season as a surprise for its fans in March 1926. The Swiss brand was perhaps the most commonly used one in Czechoslovak football stadiums in the interwar period. The neighbouring Sparta stadium acquired its iconic Omega clock with the "slender proportions" 65 of its pedestal in 1929, though a pair of smaller Zenith clocks (another Swiss brand, one for the time of day, the other for the minutes of the half) can be seen in older photographs from the second half of the 1920s. A standard stadium clock had a 45-minute dial, with only a minute hand, to mark the passage of play. In the 1930s, even provincial clubs acquired such stadium clocks. The national stadium at Strahov is another that offered two large parallel clocks, one for the minutes of the half, one for the time of day.

The time dimension and the rhythm of life at the football stadiums was fundamentally transformed by the introduction of floodlights, too, just as public lighting had created evening life in modern cities in the nineteenth century. ${ }^{66}$ For long decades, football had depended on sunlight. In the early days, a lot of matches had to be left unfinished due to nightfall. A sufficient and even illumination of the field was technologically problematic until the 1930s. This is why the football bustle had quietened down naturally with dusk. DFC Prag installed electric lighting at its sporting field as early as 1909 to enable - among other things - "the finishing of football matches at dusk". ${ }^{67}$ Apparently, no real floodlit matches after nightfall were planned. Some provincial clubs had electric lights installed at their stadiums after 1918 but their use for entire football matches still remains questionable. ${ }^{68}$

When fully-fledged floodlights were introduced in Czechoslovakia in 1935, they brought a new kind of experience to the spectators that resembled a theatre performance more than sport at first. The football field flooded by white light was described as a "fairy-tale view of the glistening lawn" by early observers. At the highest level, floodlight had its premiere at the new Masaryk National Stadium on 10 October 1935. As mentioned above, the sporting site was opened before its completion to enable more spectators to watch the Mitropa Cup finals between Sparta and Ferencvárosi TC than the Sparta Stadium could admit. This meant that some of the planned components, including the floodlights, were installed by 15 September 1935. Four 30-meter-high steel poles were built in the corners of the stadium, each of which carried 20 highperformance spotlights ( 85 centimetres in diameter, each weighing 42 kilograms, produced by the Moravia-based company Wagner a spol. Olomouc - Postrelmov).

The first match under floodlight was organized especially for this occasion. The Czechoslovak and Hungarian top-flight league winners of the previous season, SK Slavia Prague and Újpesti FC, were booked. Only 10-12,000 spectators watched the

65 Zajímavá momentka ze zápasu Sparta - U. T. E., Národní listy, 19. 8. 1929, no. 188, 4.

66 SCHIVELBUSCH, Lichtblicke.

67 Intimní Praha, 1, 23. 12. 1909, no. 33, 14.

68 Nová sokolovna v Litovli, Lidové noviny, 13. 1. 1935, no. 22, 6. 
game, mainly because the match was played on a working day (a Thursday). Technically, however, the event, that started off a long tradition of "evening matches" lasting until today, was a success. ${ }^{69} \mathrm{It}$ showed that one need not wait until the weekend to organize an international match. Stadiums of the important clubs in Czechoslovakia acquired floodlighting mostly long after 1945, though Josef Křiž's drafts for the new Slavia stadium of 1936, for instance, counted on its implementation, too..$^{70}$ This was not realized though, as Slavia, persecuted by the communist regime, had to leave Letná Plain after the coup of 1948.

\section{Conclusions}

Though severely criticized by many, Masaryk National Stadium was exceptional in the context of Czechoslovak sports sites in that it heralded the new, yet shortlived period, interrupted by the Nazi occupation and World War II. It was built with a clear urbanistic idea, as a part of a complex national sporting site. It was also by far the largest football stadium in Prague, offering technical novelties such as efficient floodlights and other advantages. Unlike Sparta Stadium, it was built from scratch, it grew not organically and did not look so aesthetically erratic and thrown together. On the other hand, it was used for various other sporting events apart from football, too, such as the Archery World Championship of 1936, the European Motorcycle Speedway Championship of 1937 and the Gymnastics World Championship of 1938. With football not having domination, it was mostly treated with a cool distance by the fans and sometimes even the officials. Also, its gently raked stands did not match the steep terraces of the rival Praterstadion in Vienna, which granted a better view of the pitch.

The drafts of the Slavia Stadium of 1936 show that the trends of the Masaryk National Stadium were becoming general. Stadiums were now understood not only as a technical and architectonic challenge but also as an active means of urbanization. The production of space both inside and out was solved with growing sophistication. Questions of fluent public and individual transportation of the masses to and from the stadium or arrival and departure to and from the stands were submitted to expert analyses in the technical or psychological aspects. ${ }^{71}$ Some architecture magazines published special issues dedicated to sport and physical culture, such as Stavba (Construction) in 1936/1937. ${ }^{72}$ Unlike the unregulated stadiums of the earlier era, the new sporting sites of the late 1930s were to be surrounded by parks and elaborate pathway systems. Kř́žz's draft for Slavia Stadium, which was one of the four proposals that received the highest praise in the architecture competition, was even submitted under the telling motto "Park adaptation" (Sadová úprava), while the other authors used rather sporty emblematics (Jan Zázvorka's "6:0", Václav Slavík's "Three Circles" - "Tři kruhy", Ferdinand Balcárek and Karel Kopp's "123").73 Though today's art historians are impressed by Slavík's draft the most, ${ }^{74}$ Slavia allegedly bought Křiž's project. According to Kríž, the stadium should have had the form of a giant oval, with roofed stands for

69 Slavia výborně representovala náš football v boji s mistrem Mad'arska, Polední list, 11. 10. 1935, no. $281,8$.

70 SK. Slavia si postaví na Letné nové hřiště, STAR, 10, 1936, no. 13 (523), 9.

71 PELC, Sport a česká společnost.

72 Stavba 13, 1936-1937, no. 6.

73 Výsledek soutěže na stavbu stadionu Slavie v Praze, Národní osvobození, 13. 3. 1936, no. 62, 6. Slavia obohatí náš sport velkolepým stadionem! Nedělní list, 14. 11. 1937, no. 316, 14.

74 ŠVÁCHA, Demokratizace sportu, 116. 
8,000 spectators on one of its long sides. Křiž's project planned for a restaurant on the ground floor and a café on the first floor, too. Furthermore, no future stadium should lack its own parking lots for the growing number of motorized fans.

The increasing scientification of stadiums can also be illustrated by the way even grass as the playing surface had become a topic of a scholarly study by 1939 . The Russian immigrant to Prague Vasilij Vukolov of the National Agriculture Research Institute published a paper entitled "Prague's decorative and playground lawns" in 1939 in which he judged - among others - the quality of the lawns at Sparta and Masaryk National Stadiums. ${ }^{75}$ He compared the density, structure and colour of the turf. Not surprisingly he chose the two stadiums that appeared most frequently in this study. These were the two, partly rival, stadiums where the most important matches were played and the most innovations were to be seen.

Translated by Sean Mark Miller, MA

\section{REFERENCES}

\section{Archival sources}

Archiv hlavního města Prahy [Metropolitan Archive Prague], Magistrát hlavního města Prahy II [Magistrate of the Capital City of Prague]

\section{Old print}

BALCÁREK, Ferdinand - KOPP, Karel. Masarykův státní stadion na Strahově. In: Architekt SIA 37, 1938, pp. 109-121.

Čas, 1921

Expres, 1936

Fotobanka ČTK, ID no. F202006091649201.

HLAVÁČ, Jaroslav - KNOTEK, Daniel. Soutěžný návrh stadionu pro město Náchod.

In: Architektura 3, 1941, pp. 203-204.

Intimní Praha, 1909

KINCL, Josef [recte Jaroslav] - KRČA, Lev - TOBEK, Stanislav. Sportovní stadion

Vítkovických železáren v Moravské Ostravě-Vítkovicích. In: Architektura 2, 1940, pp. 84-86.

KREJCAR, Jaromír. Zachraňte Letnou pro sport. In: Lidové noviny, 23. 6. 1929, no. 316, 14.

Lidové noviny, 1935

Moravská orlice, 1938

Národní listy, 1904, 1908, 1911, 1912, 1922, 1929

Národní osvobození, 1936

Nedělní list, 1937

Oficielní katalog. Výstavy tělesné výchovy a sportu republiky Čsl. v Pardubicích. Pardubice: s. n., 1931.

OLSEN [pseud.]. Nové hřiště Slavie. In: Časovosti, 1. 8. 1901, no. 22, unnumbered pages. Pestrý týden, 1932

POLÁČEK, Karel. Muži v offsidu. Ze života klubových př́vrženců. Praha: Fr. Borový, 1931. Polední list, 1931, 1934-1936, 1938

Pondělní list, 1930, 1934.

POLÍVKA, Karel. Stadiony. In: Časopis československých architektů 23-24, 1923-1924, pp. $155-170$.

Prager Tagblatt, 1896-1898, 1934

REISNER, Karel. Sportovním týdnem. In: Časovosti, 3. 4. 1902, no. 5, unnumbered pages. ROSENBAUM, Siegfried. Fußballwettspiele. In: Prager Tagblatt, 24. 3. 1894, no. 82, p. 4.

75 VUKOLOV, Pražské okrasné a hriš̌tové trávníky. 
Slovenský denník, 1937

Sport, 1914

Sport a hry, 1912

Sportsman, 1919-1921

STAR, 1935, 1936

Stavba, 1936

Večer, 1921

Volné směry, 1936

VUKOLOV, Vasilij. Pražské okrasné a hřištové trávníky. Praha: Svaz okrašlovací a ochranný, 1939.

ŽENATÝ, M. E., Všesportovní stadion v Praze. In: Stavitel 4, 1922-1923, Technická

a konstruktivistická hlídka, pp. 5-6.

\section{Bibliography}

BALE, John. Landscapes of Modern Sport. New York: St. Martin s Press, 1994.

BALE, John. Sport, Space, and the City. London; New York: Routledge, 1993.

BALE, John. Stadien als Grenzen und Überwachungsräume. In: MARSCHIK, Matthias -

MÜLLNER, Rudolf - SPITALER, Georg - ZINGANEL, Michael (eds.). Das Stadion.

Geschichte, Architektur, Politik, Ökonomie. Wien: Turia + Kant, 2005, pp. 31-48.

BALE, John - MOEN, Olof. The Stadium and the City. Keele: University Press, 1995.

BECKER, Jochen. Logistik der Massen. In: MARSCHIK, Matthias - MÜLLNER, Rudolf SPITALER, Georg - ZINGANEL, Michael (eds.). Das Stadion. Geschichte, Architektur,

Politik, Ökonomie. Wien: Turia + Kant, 2005, pp. 343-364.

CAILLOIS, Roger. Man, Play and Games. Urbana; Chicago: Illinois University Press, 2001.

FINK, Eugen. Oasis of Happiness. Thoughts Toward an Ontology of Play. Play as Symbol of

the World and Other Writings. Bloomington, Indiana: Indiana University Press, 2016.

FISCHER, Joachim (ed.). German Football Stadiums. Köln: Daab, 2006.

FLOWERS, Benjamin S. Sport and Architecture. London; New York: Routledge, 2017.

FLOWERS, Benjamin. Stadiums: Architecture and the Iconography of the Beautiful Game.

In: HUGGINS, Mike - O MAHONY, Mike (eds.). The Visual in Sport. London; New York:

Routledge, 2012, pp. 88-99.

FRANK, Sybille - STEETS, Silke (eds.). Stadium Worlds. Football, space and the built environment. London; New York: Routledge, 2010.

GAFFNEY, Chris - BALE, John. Sensing the Stadium. In: BALE, John - VERTINSKY, Patricia (eds.). Sites of Sport. Space, Place and Experience. London; New York: Routledge, 2004, pp. 25-38.

HOLZMEISTER, Antonio. A brief history of soccer stadiums in Brazil. In: Soccer \& Society, 2014 , vol. 15 , no. 1 , pp. $65-80$.

HORAK, Roman - MADERTHANER, Wolfgang. Mehr als ein Spiel. Fußball und populare Kulturen im Wien der Moderne. Wien: Löcker, 1997.

INGLIS, Simon. Sightlines. A Stadium Odyssey. London: Yellow Jersey, 2000.

INGLIS, Simon. The Football Grounds of Europe. London: Willow Books, 1990.

INGLIS, Simon. The Football Grounds of Great Britain. London: Willow Books, 1987.

KEYS, Barbara. Senses and Emotions in the History of Sport. In: Journal of Sport History, 2013, vol. 40, no. 1, pp. 21-38.

KUŽEL, Petr. Společensko-ekonomické proměny sportovních spolků a vznik fotbalových klubů $v$ pražských městech a predměstích před rokem 1914. PhDr. thesis, Univerzita Karlova v Praze, 2016.

LEFEBVRE, Henri. The Production of Space. Oxford: Blackwell, 2005.

LEO, Per. Das Stadion. In: GEISTHÖVEL, Alexa et al. Orte der Moderne. Erfahrungswelten des 19. und 20. Jahrhunderts. Frankfurt am Main: Campus Verlag, 2005, pp. 151-162.

MARSCHIK, Matthias. Bewegte Körper. Historische Populärkulturen des Sports in Österreich. Wien: LIT Verlag, 2020.

McGOWAN, Lee. Football in Fiction. A History. Abingdon; New York: Routledge, 2020. 
MÜLLNER, Rudolf. Wiener Stadion. In: MARSCHIK, Matthias - MÜLLNER, Rudolf SPITALER, Georg - ZINGANEL, Michael (eds.). Das Stadion. Geschichte, Architektur, Politik, Ökonomie. Wien: Turia + Kant, 2005, pp. 175-210.

PELC, Martin. Fotbal jako faktor československo-rakouských vztahů (1918-1938). Conference proceedings Demokratická monarchie, nedemokratická republika? Kontinuity a zlomy mezi monarchií a republikou ve střední Evropě. Praha: Masarykův ústav a Archiv Akademie věd České republiky (in print).

PELC, Martin. Národní stadion. Polemiky o ústředním sportovišti Československa 1918-1938. In: Moderní dèjiny, 2018, vol. 26, no. 1, pp. 67-90.

PELC, Martin. Sport a česká společnost do roku 1939. Osobnosti - instituce - reflexe. Praha: Nakladatelství Lidové noviny, 2018.

RANDL, Christoph. Das Fußballstadion. In: HERZOG, Markwart - von BERG, Ulrich (eds.). Fußball als Kulturphänomen. Kunst, Kult, Kommerz. Stuttgart: Kohlhammer, 2002, pp. 179-196.

RIESS, Steven A. City Games. The Evolution of American Urban Society and the Rise of Sports. Urbana; Chicago: University of Illinois Press, 1991.

SCHIVELBUSCH, Wolfgang. Lichtblicke. Zur Geschichte der künstlichen Helligkeit im 19. Jahrhundert. München; Wien: Fischer Taschenbuch, 1987.

ŠVÁCHA, Rostislav. Demokratizace sportu. In: ŠVÁCHA, Rostislav (ed.). Naprej! Česká sportovní architektura 1567-2012. Praha: Prostor, 2012, pp. 42-59.

ŠVÁCHA, Rostislav. Sport v Československé republice. In: ŚVÁCHA, Rostislav (ed.). Naprej! Česká sportouní architektura 1567-2012. Praha: Prostor, 2012, pp. 106-123.

TERRET, Thierry - HECK, Sandra (eds.). Sport and Urban Space in Europe. Facilites. Industries. Identities. London; New York: Routledge, 2016.

WEIHSMANN, Helmut. Das Rote Wien. Sozialdemokratische Architektur und Kommunalpolitik 1919-1934. Wien: Promedia, 2002.

ZWICKER, Stefan. Allerlei Pioniere: Wie der Fußball um und nach 1890 nach Prag kam. In: Karla Vymětalová - Jiří Knapík (eds.). Processes of Cultural Exchange in Central Europe in 1800-2000. Opava: Slezská univerzita v Opavě, 2014, pp. 286-299. 